\title{
ACSL1 Regulates TNF $\alpha$-Induced GM-CSF Production by Breast Cancer MDA-MB-231 Cells
}

\author{
Reeby Thomas ${ }^{1,+}$, Fatema Al-Rashed ${ }^{1, \dagger}$, Nadeem Akhter ${ }^{1}$, Fahd Al-Mulla ${ }^{2}$ \\ and Rasheed Ahmad 1,*(D) \\ 1 Microbiology \& Immunology Department, Dasman Diabetes Institute, Kuwait City, Kuwait; \\ Reeby.Thomas@dasmaninstitute.org (R.T.); fatema.alrashed@dasmaninstitute.org (F.A.-R.); \\ nadeem.akhter@dasmaninstitute.org (N.A.) \\ 2 Genetics and Bioinformatics Department, Dasman Diabetes Institute, Kuwait City, Kuwait; \\ fahd.almulla@dasmaninstitute.org \\ * Correspondence: rasheed.ahmad@dasmaninstitute.org; Tel.: 965-2224-2999 (ext. 4311); Fax: 965-2249-2406 \\ + These authors contributed equally to this paper.
}

Received: 6 August 2019; Accepted: 27 September 2019; Published: 1 October 2019

check for updates

\begin{abstract}
Overexpression of granulocyte-macrophage colony-stimulating factor (GM-CSF) in different types of cancer is associated with tumor growth and progression. Tumor necrosis factor- $\alpha$ (TNF $\alpha)$ is involved in the induction of GM-CSF in different cells; however, the underlying molecular mechanism in this production of GM-CSF has not been fully revealed. Recently, it was noted that TNF $\alpha$ mediates inflammatory responses through long-chain acyl-CoA synthetase 1 (ACSL1). Therefore, we investigated the role of ACSL1 in the TNF $\alpha$ mediated production of GM-CSF. Our results showed that MDA-MB-231 cells displayed increased GM-CSF mRNA expression and secretion after incubation with TNF $\alpha$. Blocking of ACSL1 activity in the cells with triacsin C markedly suppressed the secretion of GM-CSF. However, inhibition of $\beta$-oxidation and ceramide biosynthesis were not required for GM-CSF production. By small interfering RNA mediated knockdown, we further demonstrated that TNF $\alpha$ induced GM-CSF production was significantly diminished in ACSL1 deficient cells. TNF $\alpha$ mediated GM-CSF expression was significantly reduced by inhibition of p38 MAPK, ERK1/2 and NF- $\mathrm{BB}$ signaling pathways. TNF $\alpha$ induced phosphorylation of p38, ERK1/2, and NF- $\mathrm{BB}$ was observed during the secretion of GM-CSF. On the other hand, inhibition of ACSL1 activity attenuates TNF $\alpha$ mediated phosphorylation of p38 MAPK, ERK1/2, and NF- $\mathrm{B}$ in the cells. Importantly, our findings suggest that ACSL1 plays an important role in the regulation of GM-CSF induced by TNF $\alpha$ in MDA-MB-231 cells. Therefore, ACSL1 may be considered as a potential novel therapeutic target for tumor growth.
\end{abstract}

Keywords: ACSL1; TNF $\alpha$; GM-CSF; MDA-MB-231

\section{Introduction}

Granulocyte-macrophage colony-stimulating factor (GM-CSF), also known as colony-stimulating factor 2 (CSF2), is a growth factor/cytokine which regulates the maturation and differentiation of hematopoietic cells [1]. Dysregulation of GM-CSF is involved in chronic inflammatory diseases by the migration of myeloid cells to inflammation sites, sustaining the survival of target cells and promoting the renewal of macrophages [2]. In this context, a pathogenic role of elevated GM-CSF has been reported in autoimmune diseases that are dependent on cellular immune responses, such as multiple sclerosis (MS) and rheumatoid arthritis (RA) [3,4]. A protective role of GM-CSF has also been reported in some autoimmune diseases such as myasthenia gravis (MG), Hashimoto's thyroiditis (HT), inflammatory bowel disease (IBD), and systemic lupus erythematosus (SLE) [5-8]. Many studies 
show the involvement of GM-CSF in promoting tumor growth and progression. GM-CSF promotes cancer cell proliferation and migration in a wide variety of tumors and multiple cancer models. In this connection, multiple cancer models show constitutive GM-CSF protein expression and secretion, often together with its conjugate receptors [9]. In colorectal cancer patients, an increased level of GM-CSF in serum is considered as a potential diagnostic and prognostic marker for poor prognosis [10]. Furthermore, high GM-CSF protein levels have been related to tumor growth and poor prognosis in patients with head/neck and lung cancers [11].

GM-CSF is produced by multiple cell types such as activated monocytes, macrophages, $\mathrm{T}$ cells, B cells, fibroblasts, mast cells, vascular endothelial cells, and a wide variety of cancer cell types [8]. GM-CSF expression is induced by lipopolysaccharide and proinflammatory cytokines, including IL-1 [12], IL-6 [13], and tumor necrosis factor- $\alpha$ (TNF $\alpha)$ [14]. Increased circulating levels of TNF $\alpha$ and GM-CSF have been found in inflammatory disorders and multiples cancers [15]. However, the mechanism by which TNF $\alpha$ induces GM-CSF remains elusive. Herein, we determined whether TNF $\alpha$ could induce GM-CSF production in MDA-MB-231 breast cancer metastatic cells, and if so, which signal transduction pathway(s) were involved. Since acyl-CoA synthetase 1 (ACSL1) is involved in TNF $\alpha$ mediated immune responses [16], we investigated the role of ACSL1 in the TNF $\alpha$ mediated GM-CSF production. We found that pharmacologic and genetic inhibition of ACSL1 suppressed TNF $\alpha$-induced GM-CSF expression in MDA-MBA-231 cells along with the activation of P38 MAPK, ERK1/2, and NF-KB. However, there is no role of $\beta$-oxidation and ceramide biosynthesis in $\mathrm{TNF} \alpha$ induction of GM-CSF in MDA-MB-231.

\section{Results}

\subsection{TNF $\alpha$ Induces GM-CSF Gene Expression in Human MDA-MB-231 Cells}

Previous studies have shown that TNF $\alpha$ activates MMP-9 gene expression in MDA-MB-231 cells [17]. However, since GM-CSF induction by TNF $\alpha$ in MDA-MB-231 cells has not yet been studied, we looked at the impact of TNF $\alpha$ on the regulation of GM-CSF gene expression in these cells. To examine whether TNF $\alpha$ can induce gene expression of GM-CSF, we treated MDA-MB-231 cells with TNF $\alpha$ for $24 \mathrm{~h}$ in serum-free media. Our data show (Figure 1A) that GM-CSF mRNA expression levels were significantly higher (14.02-fold; $p<0.001)$ in TNF $\alpha$-treated MDA-MB-231 cells than those of controls (cells treated with vehicle only). Concordantly, GM-CSF protein levels (Figure 1B) were significantly higher in MDA-MB-231 cells supernatant after stimulation with TNF $\alpha(1820.67 \mathrm{pg} / \mathrm{mL} ; p<0.0001)$. Confocal microscopy along with fluorescence intensity of MDA-MB-231 cells also showed that there was a significant increase in the expression of GM-CSF in the cells treated with TNF $\alpha$ (Figure 1C,D).

\subsection{TNF $\alpha$ Induced GM-CSF Production is Suppressed by Inhibition of ACSL1}

Emerging evidence suggests that ACSL1 is involved in TNF $\alpha$ mediated immune regulation $[16,18]$. We therefore examined whether ACSL1 was required for TNF $\alpha$ induced GM-CSF production by MDA-MB-231 cells, and we used triacsin C to inhibit ACSL1 activity in MDA-MB-231 cells and measured the GM-CSF. Our data show that pretreatment of the MDA-MB-231 cells with triacsin C, followed by the exposure to $\mathrm{TNF} \alpha$, caused a significant inhibition in the expression of GM-CSF (Figure 2A,B; $p$ < 0.05). Since TNF $\alpha$ activates GM-CSF gene expression via ACSL1 which directs fatty acids towards $\beta$-oxidation [19] and ceramide production [20], we asked whether these components play a role in TNF $\alpha$ induced GM-CSF production. To this end, MDA-MB-231 cells were treated with inhibitors of fatty acid oxidation (etomoxir) or ceramide synthesis (myriocin) prior to incubation with TNF $\alpha$. We found that etomoxir and myriocin did not block the TNF $\alpha$ induced production of GM-CSF (Figure 2A,B). 
A

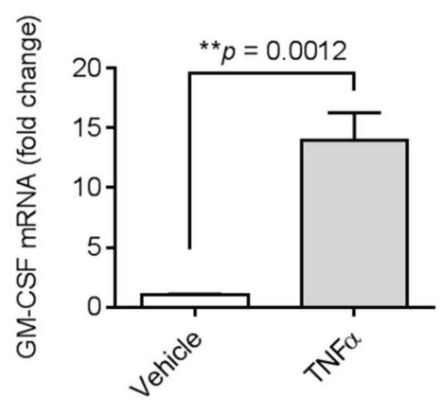

C

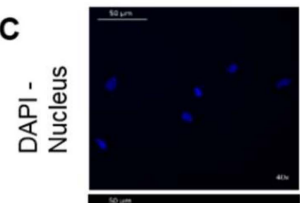

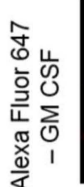

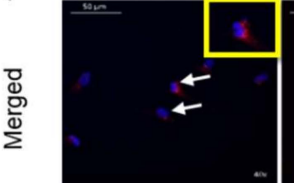

Vehicle
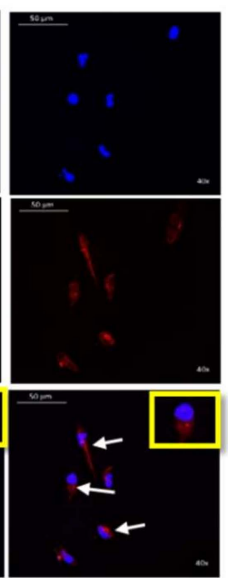

TNFa

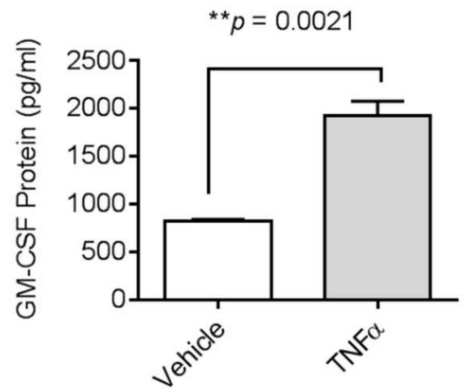

D

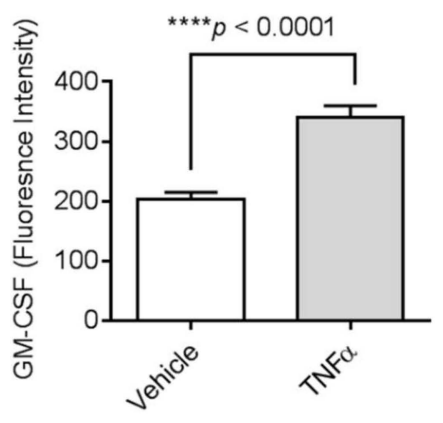

Figure 1. Effect of tumor necrosis factor- $\alpha(\mathrm{TNF} \alpha)$ on granulocyte-macrophage colony-stimulating factor (GM-CSF) production in human MDA-MB-231 cells. MDA-MB-231 cells were cultured in 6-well plates at a concentration of $1 \times 10^{6}$ cells/well. Cells were treated with vehicle and TNF $\alpha(2 \mathrm{ng} / \mathrm{mL})$, separately. After $24 \mathrm{~h}$ incubation, cells and supernatants were collected. (A) Total cellular RNA was isolated and GM-CSF mRNA expression was determined by real-time PCR. (B) Secreted GM-CSF in culture media was determined by ELISA. (C) MDA-MB-231 cells were treated with vehicle or TNF $\alpha$ for $24 \mathrm{~h}$ and then were stained with GM-CSF (red) and DAPI (blue). White arrows indicate typical stained cells. (D) GM-CSF fluorescence intensity is shown. The results obtained from three independent experiments are shown. All data are expressed as mean $\pm \operatorname{SEM}(n \geq 3)$. ${ }^{* *} p<0.01$, ${ }^{* * * *} p<0.0001$ versus vehicle.

Our confocal microscopy data along with fluorescence intensity of MDA-MB-231 cells also showed that there was a decrease in the expression of GM-CSF in triacsin C treated cells in response to TNF $\alpha$ (Figure 2C,D; $p<0.0001$ ). Inhibition of ACSL1 significantly blocks the expression of GM-CSF in MDA-MB-231 cells. 
A

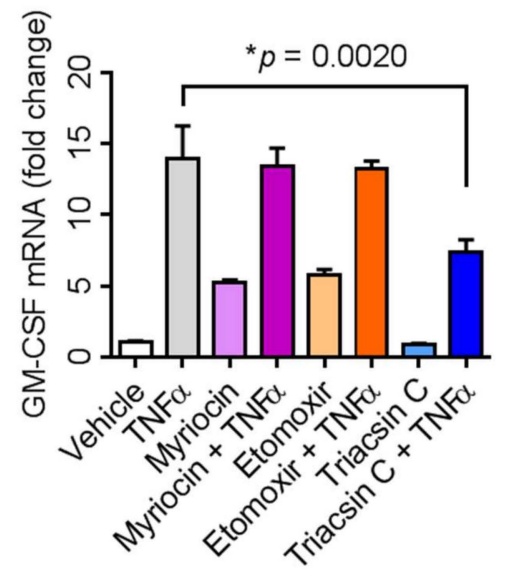

B

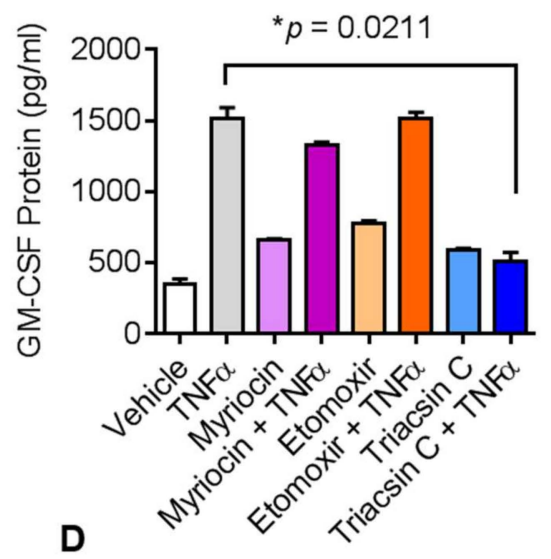

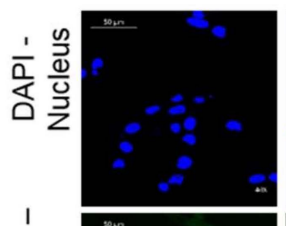
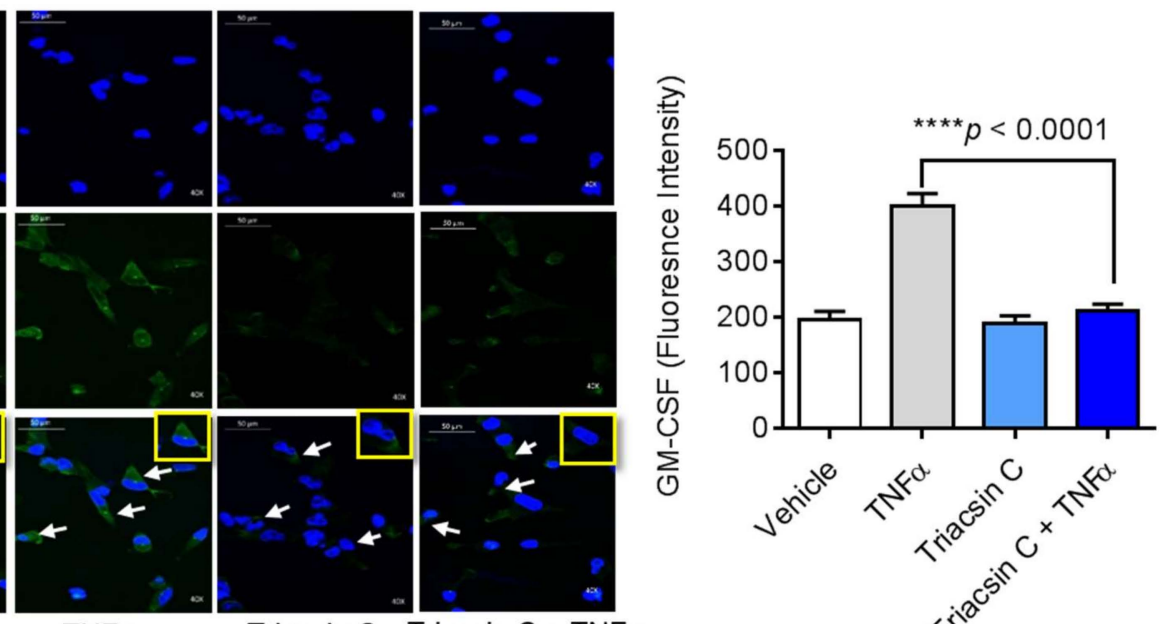

$\sum_{0}^{1}$

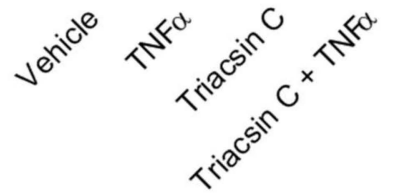

Figure 2. Effect of acyl-CoA synthetase 1 (ACSL1) inhibition on GM-CSF production in MDA-MB-231 cells. MDA-MB-231 cells were pretreated with a long-chain ACSL1 inhibitor (triacsin C, $5 \mu \mathrm{M}$ ), a serine palmitoyltransferase inhibitor (SPT-1) involved in sphingolipid biosynthesis (myriocin, $1 \mu \mathrm{M}$ ), a carnitine palmitoyltransferase 1 (CPT-1) inhibitor (etomoxir, $10 \mu \mathrm{M}$ ), or vehicle for $1 \mathrm{~h}$ and then incubated with TNF $\alpha$ for $24 \mathrm{~h}$. (A) GM-CSF mRNA was determined by real-time PCR. (B) Secreted GM-CSF in culture media was determined by ELISA. (C) MDA-MB-231 cells were stained with GM-CSF (green) and DAPI (blue). White arrows indicate typical stained cells. (D) GM-CSF fluorescence intensity was determined. All data are expressed as mean $\pm \operatorname{SEM}(n \geq 3) .{ }^{*} p<0.05,{ }^{* * * *} p<0.001$ versus vehicle.

\subsection{ACSL1 Deficiency Suppresses TNF $\alpha$-Induced GM-CSF}

To further verify if TNF $\alpha$-induced GM-CSF in the MDA-MB-231 cells was dependent on ACSL1, we transfected cells with ACSL1 siRNA, which achieved more than $80 \%$ reduction in ACSL1 mRNA levels compared with scramble (control) siRNA (Figure 3A). As expected, the GM-CSF gene expression was significantly reduced in ACSL1 siRNA transfected cells after stimulation with TNF $\alpha$ as compared with scramble siRNA transfected cells (Figure 3B). Similarly, GM-CSF protein expression was also significantly suppressed $(p<0.001)$ in ACSL1 deficient cells activated with TNF $\alpha$ (Figure 3C). Altogether, our results show that ACSL1 is a key effector in TNF $\alpha$ mediated GM-CSF production in MDA-MB-231 cells. 

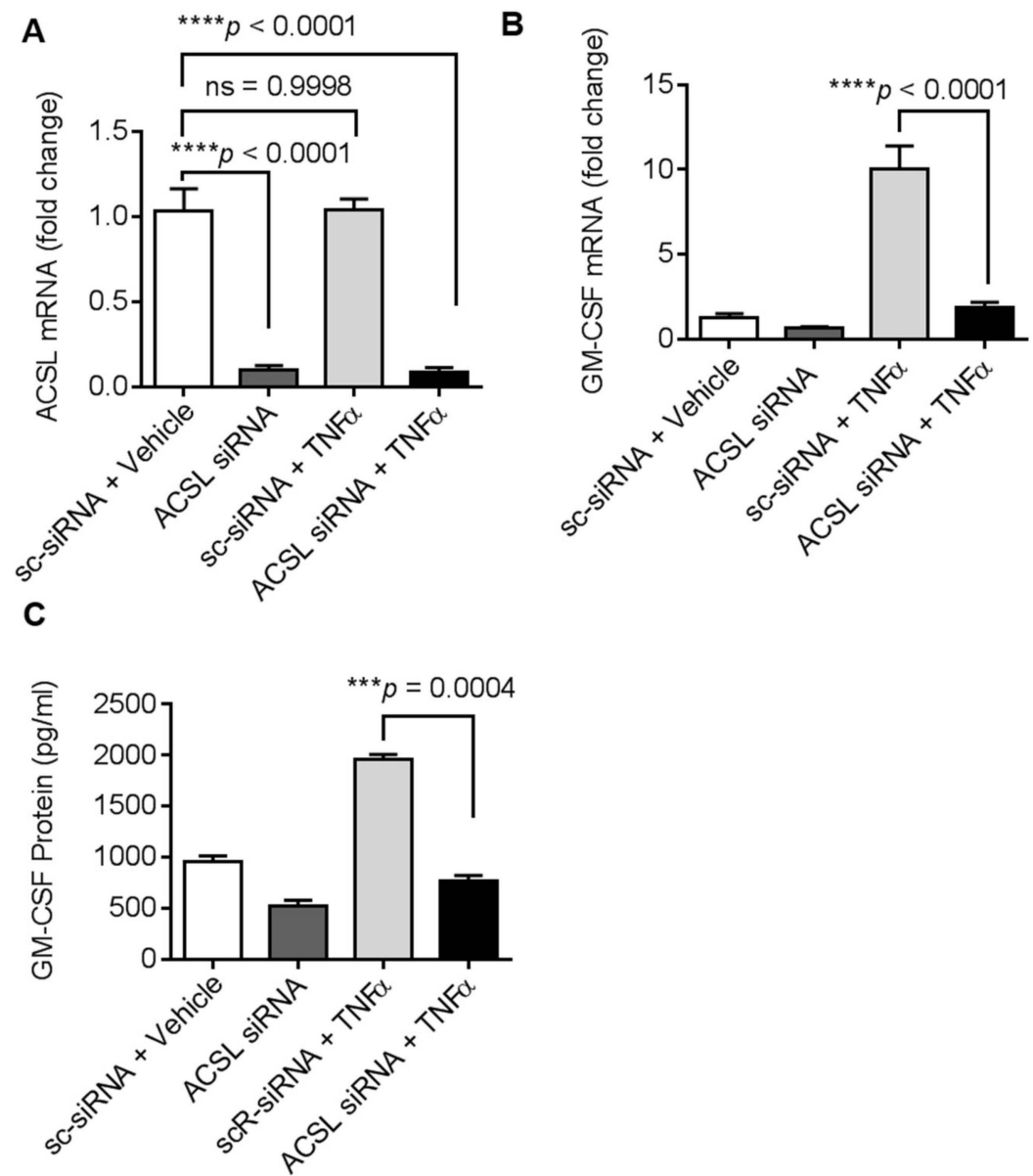

Figure 3. ACSL1 siRNA knockdown suppresses TNF $\alpha$ induced GM-CSF production. MDA-MB-231 cells were transfected with ACSL1 siRNA (targeting the human ACSL1 gene expression or scramble siRNA; a control siRNA). (A) After $36 \mathrm{~h}$, real-time PCR was performed to measure ACSL1 expression to test knocking down efficiency. (B) ACSL1 deficient cells were then treated with vehicle and TNF $\alpha$ for $24 \mathrm{~h}$. GM-CSF mRNA was determined by real-time PCR. (C) Secreted GM-CSF in culture media was determined by ELISA. All data are expressed as mean $\pm \operatorname{SEM}(n \geq 3){ }^{* * *} p<0.001,{ }^{* * * *} p<0.0001$ versus vehicle.

\subsection{ACSL1 is involved in TNF $\alpha$-Activated MAPK and NF- $\kappa B$ Signaling Pathways}

$\mathrm{TNF} \alpha$ activates MAPK signaling (ERK1/2, p38, JNK) and NF- $\mathrm{kB}$ signaling pathways [21,22]. We next asked whether these molecules are also involved in the regulation of TNF $\alpha$ stimulated GM-CSF expression in MDA-MB-231 cells. First, we determined TNF $\alpha$ mediated phosphorylation of p38 MAPK, ERK1/2, and NF- $\mathrm{KB}$ for different time points (Figure 4A). TNF $\alpha$ treatment increases the phosphorylation of 38 MAPK, ERK1/2, and NF- $\mathrm{KB}$ in a time-dependent manner. Next, we found that TNF $\alpha$ mediated expression of GM-CSF mRNA was reduced (Figure $4 B ; p<0.001$ ) by treatment with inhibitors of either p38 MAPK (SB203580), ERK1/2 (PD98059), or NF-kB (resveratrol). Consistent with qRT-PCR results, GM-CSF levels in culture supernatants of MDA-MB-231 cells were significantly reduced $(p<0.001)$ after treatment with inhibitors of either MAPKs or NF-KB (Figure 4C).

In order to gain insight into ACSL1 function in TNF $\alpha$ induced activation of MAPK and NF- $\kappa B$ signaling proteins, we treated cells with inhibitors of ACSL1 prior to TNF $\alpha$ treatment. Our results showed that ACSL1 inhibition significantly reduced TNF $\alpha$ mediated phosphorylation of p38 MAPK, ERK1/2, and NF-KB (Figure 5A-F), indicating that p38 MAPK, ERK1/2, and NF- $\mathrm{KB}$ molecules were downstream of TNF $\alpha /$ ACSL1 signaling. 


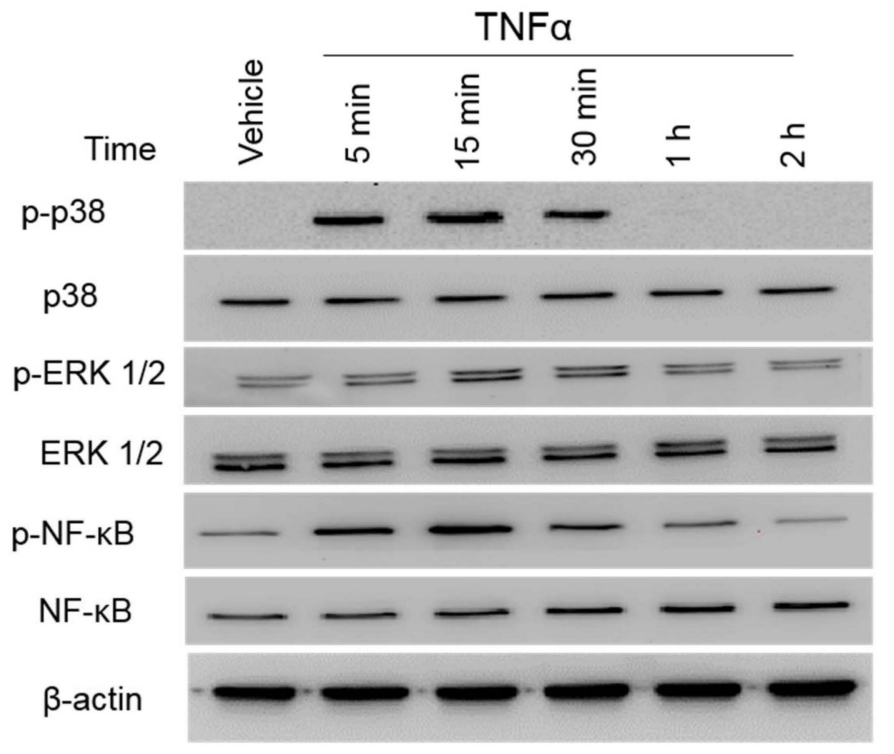

B

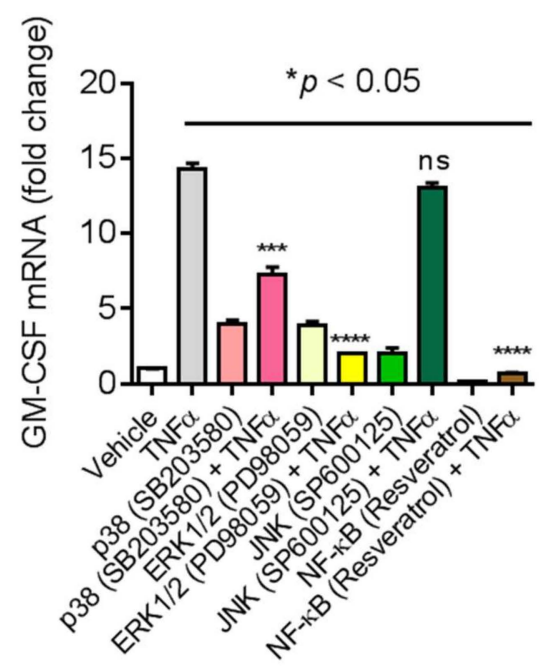

C

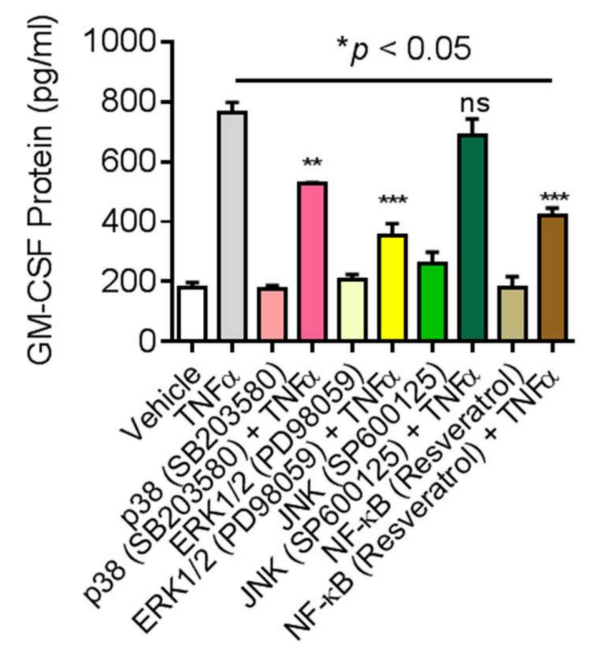

Figure 4. Effect of MAPK and NF- $\mathrm{BB}$ pathway inhibitors on TNF $\alpha$ induced GM-CSF production in MDA-MB-231 cells. (A) TNF $\alpha$ activates the MAPK/NF- $\kappa B$ signaling pathway. MDA-MB-231 cells were treated with TNF $\alpha$ for different time points and cell lysates were prepared as described in Materials and Methods. Samples were run on denaturing gels. Phosphorylated p38 MAPK, ERK1/2, and NF-KB are depicted in the upper panels and total respective proteins are shown in the lower panels. MDA-MB-231 cells were pretreated with p38 inhibitor (SB203580, 10uM; InvivoGen, San Diego, CA, USA) or ERK1/2 inhibitor (PD98059, $10 \mu \mathrm{M}$; InvivoGen, San Diego, CA, USA) or JNK inhibitor (SP600125, $10 \mu \mathrm{M})$ or NF- $\mathrm{BB}$ inhibitor (resveratrol, $1 \mu \mathrm{M}$ ) for $1 \mathrm{~h}$ and then treated with TNF $\alpha$ for $8 \mathrm{~h}$. Cells and supernatants were collected. (B) Cells were used for the isolation of total RNA to assess the GM-CSF gene expression by real-time PCR. (C) Secreted levels of GM-CSF protein were determined in supernatants by ELISA. The results obtained from three independent experiments are shown. All data are expressed as mean \pm $\operatorname{SEM}(n \geq 3) .{ }^{* * * *} p<0.001$ versus TNF $\alpha$ without respective inhibitors. 
A

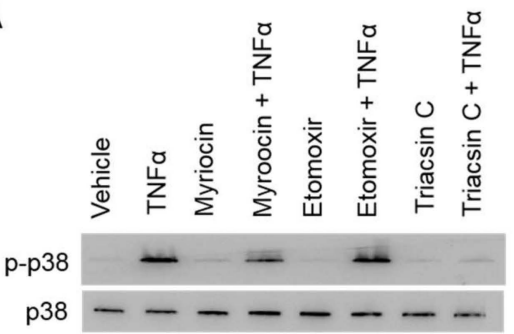

B
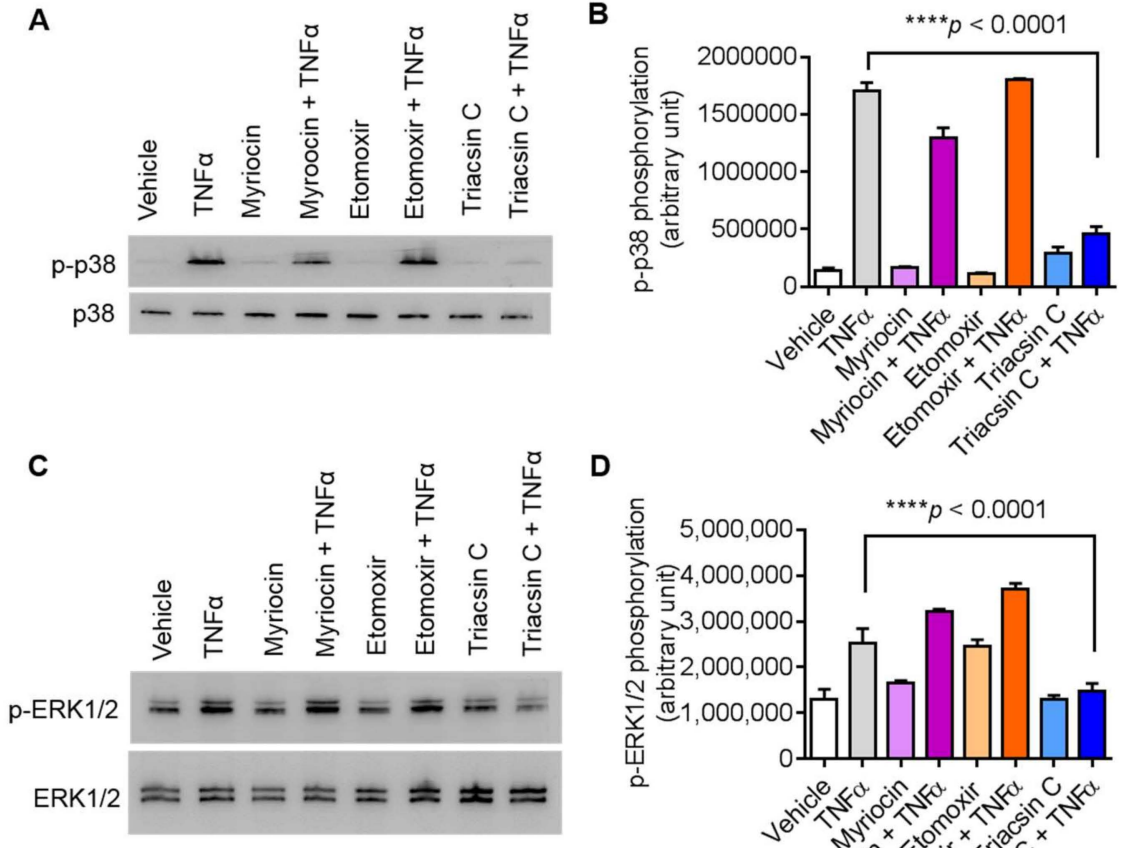

D

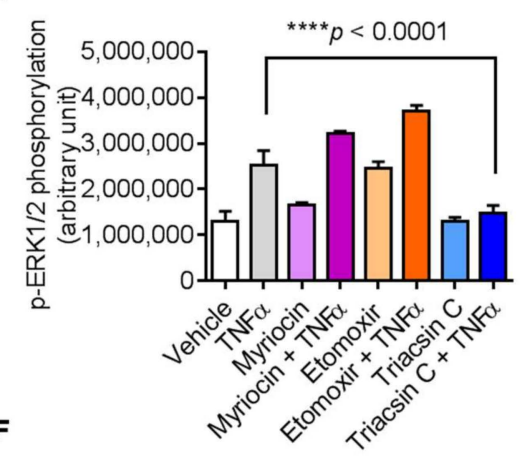

E
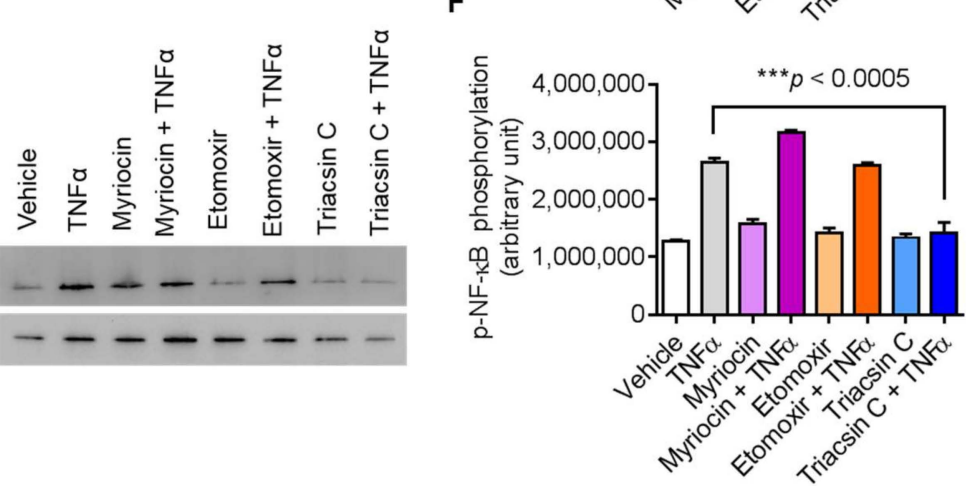

Figure 5. Inhibition of ACSL1 affects TNF $\alpha$-activated MAPK and NF- $\kappa B$ signaling pathways in MDA-MB-231 cells. As shown in Figure 4A, TNF $\alpha$ treatment increases the phosphorylation of p38 MAPK, ERK1/2, and NF- $\mathrm{B}$ in a time-dependent manner. MDA-MB-231 cells were pretreated with p38 inhibitor (SB203580, $10 \mu \mathrm{M})$, ERK1/2 inhibitor (PD98059, $10 \mu \mathrm{M})$, or NF-kB inhibitor (resveratrol, $1 \mu \mathrm{M}$ ) for $1 \mathrm{~h}$ and then treated with TNF $\alpha$ for $15 \mathrm{~min}$. Cell lysates were prepared as described in Materials and Methods. Samples were run on denaturing gels. Immunoreactive bands were developed using an Amersham ECL Plus Western Blotting Detection System (GE Healthcare, Chicago, IL, USA) and visualized by Molecular Imager@VersaDoc ${ }^{\mathrm{TM}}$ MP Imaging Systems (Bio-Rad Laboratories, Hercules, CA, USA). (A) Phosphorylated proteins p38 MAPK, (C) ERK1/2, and (E) NF-kB are depicted in the upper panels and total respective proteins are shown in the lower panels. (B, D, F) Phosphorylation intensity of p38 MAPK, ERK1/2, and NF- $\mathrm{kB}$ was quantified using Image Lab software (version 6.0.1, Bio-Rad, Hercules, CA, USA) and are presented in arbitrary units. All data are expressed as mean \pm $\operatorname{SEM}(n \geq 3) .{ }^{* * * *} p<0.001$ versus TNF $\alpha$ without respective inhibitors.

To further verify the role of ACSL1 in TNF $\alpha$ induced activation of p38 MAPK, ERK1/2, and NF- $\mathrm{BB}$ signaling proteins, we transfected MDA-MB-231 cells with ACSL1 siRNA and scramble siRNA prior to $\mathrm{TNF} \alpha$ treatment. Our results showed that ACSL1 silencing with siRNA significantly reduced TNF $\alpha$-mediated phosphorylation of p38 MAPK, ERK1/2, and NF-kB (Figure 6A-F). Overall, our results support the conclusion that p38 MAPK, ERK1/2, and NF- $\mathrm{BB}$ molecules were downstream of $\mathrm{TNF} \alpha / \mathrm{ACSL} 1$ signaling. 
A

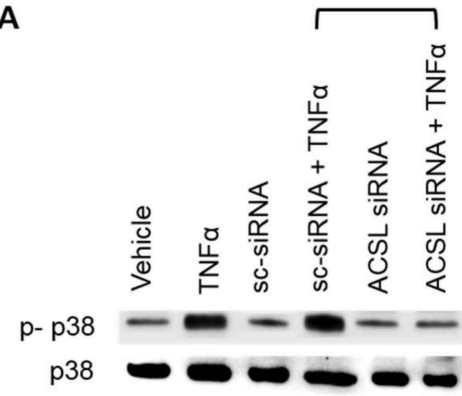

C

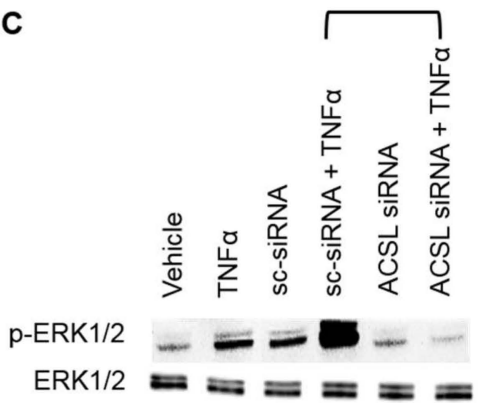

E

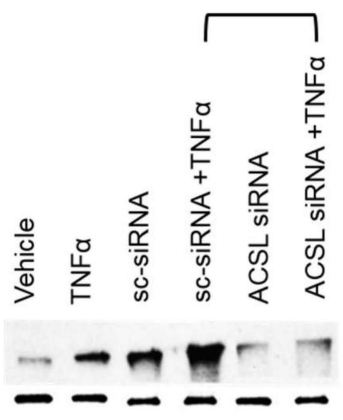

B

D

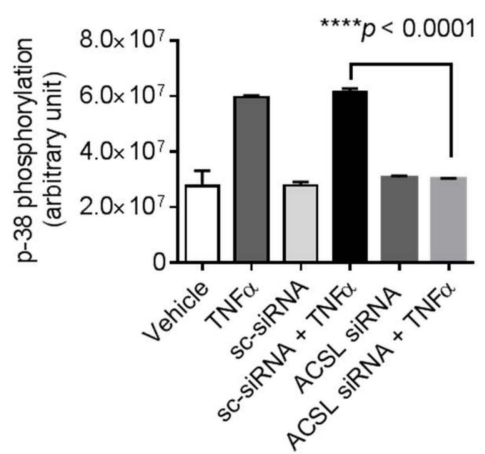

F
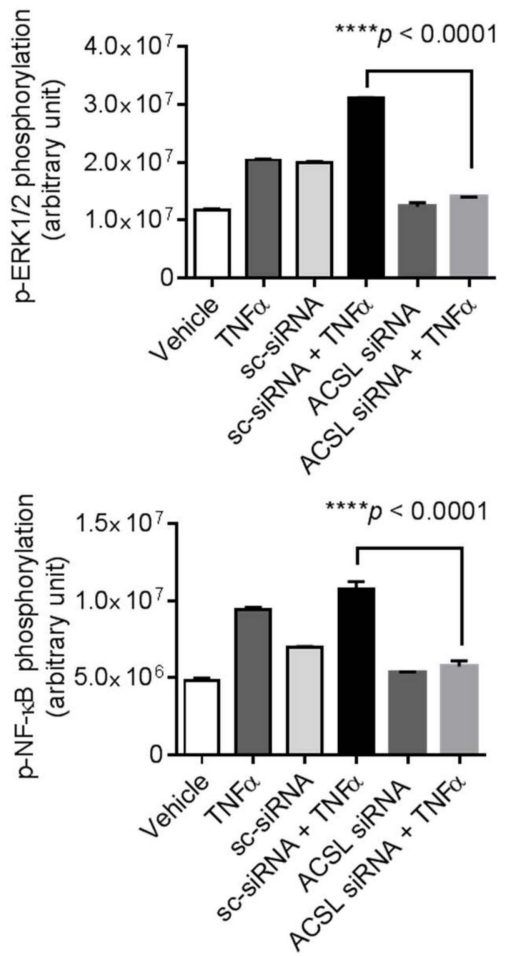

Figure 6. ACSL1 siRNA knockdown reduces the TNF $\alpha$ induced phosphorylation of p38 MAPK, ERK1/2, and NF- $k$ B. MDA-MB-231 cells were transfected with ACSL1 siRNA (targeting the human ACSL1 gene expression) or scramble siRNA (a control siRNA) and incubated for $36 \mathrm{~h}$. ACSL1 deficient cells were then treated with vehicle and TNF $\alpha$ for $15 \mathrm{~min}$. Cell lysates were prepared as described in Materials and Methods. Samples were run on denaturing gels. Immunoreactive bands were developed using an Amersham ECL Plus Western Blotting Detection System (GE Healthcare, Chicago, IL, USA) and visualized by Molecular Imager@VersaDoc ${ }^{\mathrm{TM}}$ MP Imaging Systems (Bio-Rad Laboratories, Hercules, CA, USA). (A) Phosphorylated proteins p38 MAPK, (C) ERK1/2, and (E) NF- $\mathrm{KB}$ are depicted in the upper panels and total respective proteins are shown in the lower panels. $(\mathbf{B}, \mathbf{D}, \mathbf{F})$ Phosphorylation intensity of p38 MAPK, ERK1/2, and NF- $\mathrm{KB}$ was quantified using Image Lab Software (Bio-Rad) and presented in arbitrary units. All data are expressed as mean \pm SEM. ${ }^{* * * *} p<0.001$ versus TNF $\alpha$-treated transfected cells with scramble siRNA.

\section{Discussion}

It is well established that overproduction of GM-CSF is involved in the pathogenesis of inflammatory diseases as well as tumor growth and progression $[9,23]$. In this regard, data indicated that breast cancer-derived GM-CSF supports local tumor growth and metastatic progression in preclinical models [24]. However, the underlying molecular mechanism in the overexpression of GM-CSF has not been fully understood. Our current findings demonstrate that TNF $\alpha$ induces GM-CSF in MDA-MB-231 
breast cancer metastatic cells. Evidence from in vitro studies supports a role of TNF $\alpha$ in the regulation of GM-CSF in different cell lines [25]. Therefore, our results support the hypothesis that GM-CSF induction in MDA-MB-231 cancerous cells is regulated by TNF $\alpha$. GM-CSF expression has been found, frequently together with the GM-CSF receptor, in a variety of tumor models, including small-cell lung carcinomas [26], meningiomas [27], skin carcinoma [28], gliomas [29], and head and neck squamous cell carcinomas (HNSCCs) [30]. It has been reported that high levels of IL-6 and TNF $\alpha$ are correlated with strong tumor invasiveness and poor prognosis of breast cancer [31], and our results show that TNF $\alpha$ induced GM-CSF in cancer cells, suggesting that TNF $\alpha$ may enhance tumor growth through the induction of GM-CSF.

Regarding molecular mechanism involved in TNF $\alpha$ stimulated induction of GM-CSF, recent studies have shown that ACSL1 deficiency prevents TNF $\alpha$ mediated induction of cell surface and secretory inflammatory markers in monocytic cells. Therefore, it was important to determine whether ACSL1 mediated signaling is involved in $\mathrm{TNF} \alpha$ mediated regulation of GM-CSF gene expression. In this study, we presented two forms of evidence that TNF $\alpha$ induced production of GM-CSF depends on ACSL1. First, we observed that production of GM-CSF by TNF $\alpha$ is suppressed by pharmacologic inhibition of ACSL1 with triacsin C. Second, ACSL1 deficient MDA-MB-231 cells do not support the secretion of GM-CSF in response to stimulation with TNF $\alpha$. This finding might also be explained by the observation described by Al-Rashed et al. showing that siRNA-mediated ACSL1 deficient monocytic cells demonstrate that TNF $\alpha$ induced inflammatory marker expression in monocytic cells requires ACSL1. Furthermore, ACSL1 deficiency prevents TNF $\alpha$ mediated induction of IL-1b and MCP-1 supporting the involvement of ACSL1 in the TNF $\alpha$ mediated production of cytokines and chemokines [16]. Since TNF $\alpha$ activates GM-CSF gene expression via ACSL1 which directs fatty acids towards $\beta$-oxidation [19] and ceramide production [20], MDA-Mb-231 cells were treated with inhibitors of fatty acid oxidation (etomoxir) or ceramide synthesis (myriocin) prior to incubation with TNF $\alpha$. We found that etomoxir and myriocin did not block the TNF $\alpha$ induced production of GM-CSF. Our results suggest that ACSL1 mediates inflammatory effects without significant impact on $\beta$-oxidation and ceramide formation. In this connection, a study shows that ACSL1 mediates inflammatory effect without significant involvement of $\beta$-oxidation [32].

Next, we also looked at the ACSL1 function in TNF $\alpha$ induced activation of MAPK and NF- $k B$ signaling proteins. It is well documented that TNF $\alpha$ stimulates MAPK and NF- $\mathrm{B}$ signaling pathways involved in the regulation of several inflammatory cytokines that contribute to the pathogenesis of different inflammatory conditions [21,22]. It has been reported that TNF $\alpha$ induced GM-CSF secretion by human lung fibroblasts was partially blocked by ERK inhibitor and p38 MAPK inhibitor [33]. In this context, another study showed that p38 MAPK regulates TNF $\alpha$ induced RANTES and GM-CSF production in human bronchial epithelial cells [34]. Consistent with previous findings in different cells, we found that TNF $\alpha$ induced GM-CSF production by MDA-MB-231 cells was suppressed with the inhibition of p38 MAPK and ERK1/2, suggesting that different cell lines regulate the GM-CSF production in response to TNF $\alpha$ in a similar fashion, specifically in reference to p38 MAPK. Our data also show that TNF $\alpha$ induced phosphorylation of ERK1/2, p38 MAPK, and NF- $\mathrm{BB}$ in MDA-MB-231 cancer cells. Interestingly, our first results showed that blocking of ACSL1 activity inhibited the TNF $\alpha$ mediated phosphorylation of p38 MAPK, ERK1/2, and NF- $k$ B in MDA-MB-231 cells. These results suggest that ACSL1 acts upstream of MAPK and NF- $\mathrm{KB}$ signaling pathways.

In summary, the present study demonstrated that ACSL1 plays a crucial role in the regulation of TNF $\alpha$ mediated excessive production of GM-CSF associated with the inflammatory process that is involved in tumor growth. Therefore, targeting ACSL1 may be a new therapeutic strategy to prevent the inflammatory processes involved in cancer metastasis. Since TNF $\alpha$ can induce GM-CSF expression and secretion in several cancer cells, our results may furthermore suggest that a similar pattern of mechanisms may underlie TNF $\alpha$ induced production of GM-CSF by various cancer cells and tissues. 


\section{Materials and Methods}

\subsection{Cell Culture}

The MDA-MB-231 cell line is well established as a model for cancer research related to gene regulation. The MDA-MB-231 cell line is also being used for lipid research. Human MDA-MB-231 cells were purchased from American Type Culture Collection (ATCC, Manassas, VA, USA), and then grown in DMEM culture medium (Gibco, Thermo Fisher Scientific, Waltham, MA, USA) supplemented with 10\% fetal bovine serum (Gibco, Thermo Fisher Scientific, Waltham, MA, USA), 2 mM glutamine (Gibco, Thermo Fisher Scientific, Waltham, MA, USA), $1 \mathrm{mM}$ sodium pyruvate, $10 \mathrm{mM}$ HEPES, $100 \mu \mathrm{g} / \mathrm{mL}$ Normocin, $50 \mathrm{U} / \mathrm{mL}$ penicillin and $50 \mu \mathrm{g} / \mathrm{mL}$ streptomycin (P/S; Gibco, Thermo Fisher Scientific, Waltham, MA, USA) and incubated at $37^{\circ} \mathrm{C}$ (with humidity) in $5 \% \mathrm{CO}_{2}$.

\subsection{Cell Stimulation}

MDA-MB-231 cells were plated in 12-well plates (Costar, Corning Incorporated, Corning, NY, USA) at $1 \times 10^{6}$ cells/well concentration unless otherwise indicated. Cells were treated with vehicle or $\mathrm{TNF} \alpha\left(2 \mathrm{ng} / \mathrm{mL} ; 210-\mathrm{TA}, \mathrm{R} \& \mathrm{D}\right.$ Systems, Minneapolis, MN, USA) for $24 \mathrm{~h}$ at $37^{\circ} \mathrm{C}$. After incubation, cells were harvested for RNA isolation and conditioned media were collected for measuring secreted GM-CSF. Regarding the lipid metabolic signaling pathway inhibition study, MDA-MB-231 cells were preincubated with different inhibitors (myriocin (1 $\mu \mathrm{M} / \mathrm{mL} ; \mathrm{M} 1177-5 \mathrm{MG})$, which is a serine palmitoyltransferase inhibitor (SPT-1) involved in sphingolipid biosynthesis; etomoxir $(10 \mu \mathrm{M} / \mathrm{mL} ; 236020)$, which is a carnitine palmitoyltransferase 1 (CPT-1), a mitochondrial enzyme involved in fatty acid $\beta$-oxidation; and triacsin $C(5 \mu \mathrm{M} / \mathrm{mL} ; \mathrm{T} 4540)$, which is a long-chain acyl-CoA synthetase 1 (ACSL1) inhibitor) and then treated with tumour necrosis factor- $\alpha$ (TNF $\alpha)$, (2 ng/mL; 210-TA, R\&D Systems, Minneapolis, MN, USA). All lipid inhibitors were purchased from Sigma-Aldrich (Merck KGaA, Darmstadt, Germany).

Regarding MAPK/TNF $\alpha$ signaling, cells were preincubated with different cell signaling pathway inhibitors for $1 \mathrm{~h}$ under cell culture conditions (SB203580 (10 $\mu \mathrm{M} / \mathrm{mL}$; 559389, Sigma-Aldrich, Merck KGaA, Darmstadt, Germany), a p38 inhibitor; PD98059 (10 $\mu \mathrm{M} / \mathrm{mL}$; tlrl-pd98, InvivoGen, San Diego, CA, USA), an inhibitor for ERK1/2; resveratrol (5 $\mu \mathrm{M} / \mathrm{mL}$; tlrl-resv, InvivoGen, San Diego, CA, USA), an inhibitor for NF-kB; and SP600125 (10 $\mu \mathrm{M} / \mathrm{mL} ; 420119$, Sigma-Aldrich, Merck KGaA, Darmstadt, Germany), an inhibitor for JNK signaling pathway and then cells were stimulated for $8 \mathrm{~h}$.

\subsection{Real-Time Quantitative PCR}

Total RNA was extracted from MDA-MB-231 cells using RNeasy Mini Kit (Qiagen, Valencia, CA, USA) as per the manufacturer's instructions. The cDNA was synthesized using $1 \mu \mathrm{g}$ of total RNA using a high-capacity cDNA reverse transcription kit (Applied Biosystems, Foster City, CA, USA). Real-time PCR was performed on a 7500 Fast Real-Time PCR System (Applied Biosystems, Foster City, CA, USA) using a TaqMan ${ }^{\mathrm{TM}}$ Gene Expression Master Mix (Applied Biosystems, Foster City, CA, USA). Each reaction contained 500ng cDNA that was amplified with Inventoried TaqMan Gene Expression Assay products (CSF2, Hs00929873; ACSL1, Hs00960561; GAPDH, Hs03929097_g1). The threshold cycle (Ct) values were normalized to the house-keeping gene GAPDH and the amounts of target mRNA relative to control were calculated using the $\Delta \Delta \mathrm{Ct}$-method $[35,36]$. Relative mRNA expression was expressed as fold expression over average of control gene expression. The expression level in the control treatment was assumed to be 1 . Values are presented as mean \pm SEM. Results were analyzed statistically; $p<0.05$ was considered significant.

\subsection{Small Interfering RNA (siRNA) Transfections}

MDA-MB-231 cells were washed and re-suspended in $1005 \mu \mathrm{L}$ of nucleofector solution provided with the Amaxa Nucleofector Kit V and transfected separately with siRNA-ACSL1 (30 nM; OriGene 
Technologies, Inc., Rockville, MD, USA), scramble (control) siRNA (30 nM; OriGene Technologies, Inc., Rockville, MD, USA), and pmaxGFP (0.5 $\mu \mathrm{g}$; Amaxa Nucleofector Kit V for MDA-MB-231 cells, Lonza, Basel, Switzerland). All transfection experiments were performed with an Amaxa Cell Line Nucleofector Kit V for MDA cells (Lonza, Basel, Switzerland) using an Amaxa Electroporation System (Lonza, Basel, Switzerland) according to the manufacturer's protocol [37]. After $36 \mathrm{~h}$ of transfection, cells were treated with TNF $\alpha$ for $24 \mathrm{~h}$. Cells were harvested for RNA isolation and staining study. ACSL1 gene knockdown level was assessed by real-time PCR using ACSL1 gene specific primer probes.

\subsection{GM-CSF Determination}

Secreted GM-CSF protein in supernatants of MDA-MB-231 cells stimulated with TNF $\alpha$ was quantified using sandwich ELISA following the manufacturer's instructions (DY215-05, R\&D Systems, Minneapolis, MN, USA).

\subsection{Western Blotting}

MDA-MB-231 cells treated with TNF $\alpha$ at different time points were harvested and incubated for 30 min with lysis buffer (10X Lysis Buffer, Cell Signaling, Danvers, MA, USA). The protein lysates were prepared and resolved by $12 \%$ SDS-PAGE as described earlier [38]. Cellular proteins were transferred to an Immuno-Blot Polyvinylidene difluoride (PVDF) membrane (Bio-Rad Laboratories, Hercules, CA, USA) by electroblotting. The membranes were then blocked with $5 \%$ non-fat milk in PBS for $1 \mathrm{~h}$, followed by incubation with primary antibodies against p44/42 MAPK (ERK1/2; cat\# 9101) and 44/42 MAPK (ERK1/2; cat\# 9102), p-p38 (cat\# 9211) and p38 (cat\# 9212), p-NF-кB (cat\# 3033) and NF- $\mathrm{KB}$ (cat\#3034), and $\beta$-actin (cat\# 4967) in 1:1000 dilution at $4{ }^{\circ} \mathrm{C}$ overnight. All primary antibodies were purchased from Cell Signaling (Cell Signaling Technology Inc., Danvers, MA, USA). The blots were then washed three times with TBS-T and incubated for $2 \mathrm{~h}$ with HRP-conjugated secondary antibody (Promega, Madison, WI, USA). Immunoreactive bands were developed using an Amersham ECL Plus Western Blotting Detection System (GE Healthcare, Chicago, IL, USA) and visualized by Molecular Imager@VersaDoc ${ }^{\mathrm{TM}}$ MP Imaging Systems (Bio-Rad Laboratories, Hercules, CA, USA).

\subsection{Immunocytofluorescence}

MDA-MB-231 cells $\left(10^{6} / \mathrm{mL}\right)$ were seeded on coverslips and cultured in 6-well plates at $37^{\circ} \mathrm{C}$. After incubation, the slides were then fixed in $4 \%$ formaldehyde and washed three times in cold PBS. Cells were then permeabilized in $0.1 \%$ Triton X-100, followed by three washes in cold PBS. The cells were blocked in $1 \%$ bovine serum albumin for $1 \mathrm{~h}$. The slides were incubated overnight at room temperature with primary antibody of rabbit polyclonal anti GM-CSF antibody (GTX51383 Genetex, Irvine, CA, USA) in 1:200 dilution. The cells were then washed in PBS containing 0.05\% Tween three times and again incubated with the secondary antibody conjugated with Alexa Fluor 694 or Alexa Fluor 488 (abcam@ab150079, abcam@ab150077) in 1:200 dilution for $1 \mathrm{~h}$. After washing the slide several times in PBS, the cells were counterstained and mounted with coverslip using mountant containing DAPI (Vectashield H1500, Vectorlab, Burlingame, CA, USA).

The confocal images of the MDA-MB-231 cells were collected on an inverted Zeiss LSM710 AxioObserver microscope (Carl Zeiss, Gottingen, Germany) using a Plan-Apochromat 40×/1.40 oil DIC M27 objective lens. Excitation was via a $647 \mathrm{~nm}$ HeNe solid-state laser and the $405 \mathrm{~nm}$ line of an argon ion laser. After laser excitation of the samples, optimized emission detection bandwidths were configured using Zeiss Zen 2012 control software (version 1.1.1.2.0, Gottingen, Germany). Subsequently, the confocal images were captured, and fluorescence was measured using Zeiss Zen 2012 software (Gottingen, Germany).

\subsection{Statistical Analysis}

Statistical analysis was performed using GraphPad Prism software (version 6.07, La Jolla, CA, USA). Data are shown as mean \pm standard error of the mean (SEM), unless otherwise indicated. 
One-way ANOVA followed by Tukey's test were used to compare means between groups. For all analyses, data from a minimum of three sample sets were used for statistical calculation. $p$-value $<0.05$ was considered significant. ns, no significance, ${ }^{*} p<0.05,{ }^{* *} p<0.01,{ }^{* * *} p<0.001$, and ${ }^{* * * *} p<0.0001$ )

Author Contributions: Conceptualization, R.A.; Data curation, R.T., F.A. and N.A.; Formal analysis, R.T.; Funding acquisition, R.A.; Investigation, R.T. and F.A.; Methodology, F.A. and N.A.; Supervision, R.A.; Writing-original draft, R.T. and R.A.; Writing-review \& editing, F.A. and F.A.-M.

Funding: This research was funded by the Kuwait Foundation for the Advancement of Sciences (KFAS) (Grant No. RA AH 2016-007).

Conflicts of Interest: The authors declare no conflict of interest.

\section{References}

1. Hong, I.S. Stimulatory versus suppressive effects of GM-CSF on tumor progression in multiple cancer types. Exp. Mol. Med. 2016, 48, e242. [CrossRef]

2. Wicks, I.P.; Roberts, A.W. Targeting GM-CSF in inflammatory diseases. Nat. Rev. Rheumatol. 2016, 12, 37-48. [CrossRef] [PubMed]

3. Rasouli, J.; Ciric, B.; Imitola, J.; Gonnella, P.; Hwang, D.; Mahajan, K.; Mari, E.R.; Safavi, F.; Leist, T.P.; Zhang, G.X.; et al. Expression of GM-CSF in T Cells Is Increased in Multiple Sclerosis and Suppressed by IFN-beta Therapy. J. Immunol. 2015, 194, 5085-5093. [CrossRef] [PubMed]

4. McInnes, I.B.; Schett, G. Pathogenetic insights from the treatment of rheumatoid arthritis. Lancet 2017, 389, 2328-2337. [CrossRef]

5. Cao, Y.; Amezquita, R.A.; Kleinstein, S.H.; Stathopoulos, P.; Nowak, R.J.; O'Connor, K.C. Autoreactive T Cells from Patients with Myasthenia Gravis Are Characterized by Elevated IL-17, IFN-gamma, and GM-CSF and Diminished IL-10 Production. J. Immunol. 2016, 196, 2075-2084. [CrossRef]

6. Borriello, F.; Galdiero, M.R.; Varricchi, G.; Loffredo, S.; Spadaro, G.; Marone, G. Innate Immune Modulation by GM-CSF and IL-3 in Health and Disease. Int. J. Mol. Sci. 2019, 20, 834. [CrossRef] [PubMed]

7. Eyerich, K.; Dimartino, V.; Cavani, A. IL-17 and IL-22 in immunity: Driving protection and pathology. Eur. J. Immunol. 2017, 47, 607-614. [CrossRef]

8. Lotfi, N.; Thome, R.; Rezaei, N.; Zhang, G.X.; Rezaei, A.; Rostami, A.; Esmaeil, N. Roles of GM-CSF in the Pathogenesis of Autoimmune Diseases: An Update. Front. Immunol. 2019, 10, 1265. [CrossRef]

9. Van Overmeire, E.; Stijlemans, B.; Heymann, F.; Keirsse, J.; Morias, Y.; Elkrim, Y.; Brys, L.; Abels, C.; Lahmar, Q.; Ergen, C.; et al. M-CSF and GM-CSF Receptor Signaling Differentially Regulate Monocyte Maturation and Macrophage Polarization in the Tumor Microenvironment. Cancer Res. 2016, 76, 35-42. [CrossRef]

10. Park, S.H.; Breitbach, C.J.; Lee, J.; Park, J.O.; Lim, H.Y.; Kang, W.K.; Moon, A.; Mun, J.H.; Sommermann, E.M.; Maruri Avidal, L.; et al. Phase $1 \mathrm{~b}$ Trial of Biweekly Intravenous Pexa-Vec (JX-594), an Oncolytic and Immunotherapeutic Vaccinia Virus in Colorectal Cancer. Mol. Ther. J. Am. Soc. Gene Ther. 2015, 23, 1532-1540. [CrossRef]

11. Sakakura, K.; Takahashi, H.; Kaira, K.; Toyoda, M.; Murata, T.; Ohnishi, H.; Oyama, T.; Chikamatsu, K. Relationship between tumor-associated macrophage subsets and CD47 expression in squamous cell carcinoma of the head and neck in the tumor microenvironment. Lab. Investig. J. Tech. Methods Pathol. 2016, 96, 994-1003. [CrossRef] [PubMed]

12. Parajuli, B.; Sonobe, Y.; Kawanokuchi, J.; Doi, Y.; Noda, M.; Takeuchi, H.; Mizuno, T.; Suzumura, A. GM-CSF increases LPS-induced production of proinflammatory mediators via upregulation of TLR4 and CD14 in murine microglia. J. Neuroinflammation 2012, 9, 268. [CrossRef] [PubMed]

13. Salmiheimo, A.N.; Mustonen, H.K.; Vainionpaa, S.A.; Shen, Z.; Kemppainen, E.A.; Seppanen, H.E.; Puolakkainen, P.A. Increasing the Inflammatory Competence of Macrophages with IL-6 or with Combination of IL-4 and LPS Restrains the Invasiveness of Pancreatic Cancer Cells. J. Cancer 2016, 7, 42-49. [CrossRef] [PubMed]

14. Sadeghi, K.; Wisgrill, L.; Wessely, I.; Diesner, S.C.; Schuller, S.; Durr, C.; Heinle, A.; Sachet, M.; Pollak, A.; Forster-Waldl, E.; et al. GM-CSF Down-Regulates TLR Expression via the Transcription Factor PU.1 in Human Monocytes. PLoS ONE 2016, 11, e0162667. [CrossRef] [PubMed] 
15. Komohara, Y.; Fujiwara, Y.; Ohnishi, K.; Takeya, M. Tumor-associated macrophages: Potential therapeutic targets for anti-cancer therapy. Adv. Drug Deliv. Rev. 2016, 99, 180-185. [CrossRef] [PubMed]

16. Al-Rashed, F.; Ahmad, Z.; Iskandar, M.A.; Tuomilehto, J.; Al-Mulla, F.; Ahmad, R. TNF-alpha Induces a Pro-Inflammatory Phenotypic Shift in Monocytes through ACSL1: Relevance to Metabolic Inflammation. Cell Physiol. Biochem. 2019, 52, 397-407. [CrossRef] [PubMed]

17. Kim, S.; Choi, J.H.; Kim, J.B.; Nam, S.J.; Yang, J.H.; Kim, J.H.; Lee, J.E. Berberine suppresses TNF-alpha-induced MMP-9 and cell invasion through inhibition of AP-1 activity in MDA-MB-231 human breast cancer cells. Molecules 2008, 13, 2975-2985. [CrossRef] [PubMed]

18. Bornfeldt, K.E. Growing evidence for a role for acyl-CoA synthetase 1 in immunometabolism. J. Leukoc. Biol. 2019. [CrossRef] [PubMed]

19. Ellis, J.M.; Li, L.O.; Wu, P.C.; Koves, T.R.; Ilkayeva, O.; Stevens, R.D.; Watkins, S.M.; Muoio, D.M.; Coleman, R.A. Adipose acyl-CoA synthetase-1 directs fatty acids toward beta-oxidation and is required for cold thermogenesis. Cell Metab. 2010, 12, 53-64. [CrossRef] [PubMed]

20. Goldenberg, J.R.; Wang, X.; Lewandowski, E.D. Acyl CoA synthetase-1 links facilitated long chain fatty acid uptake to intracellular metabolic trafficking differently in hearts of male versus female mice. J. Mol. Cell. Cardiol. 2016, 94, 1-9. [CrossRef]

21. Hayden, M.S.; Ghosh, S. Regulation of NF-kappaB by TNF family cytokines. Semin. Immunol. 2014, 26, 253-266. [CrossRef] [PubMed]

22. Mancuso, G.; Midiri, A.; Beninati, C.; Piraino, G.; Valenti, A.; Nicocia, G.; Teti, D.; Cook, J.; Teti, G. Mitogen-activated protein kinases and NF-kappa B are involved in TNF-alpha responses to group B streptococci. J. Immunol. 2002, 169, 1401-1409. [CrossRef] [PubMed]

23. Lowenberg, B.; Salem, M.; Delwel, R. Effects of recombinant multi-CSF, GM-CSF, G-CSF and M-CSF on the proliferation and maturation of human AML in vitro. Blood Cells 1988, 14, 539-549. [PubMed]

24. Reggiani, F.; Labanca, V.; Mancuso, P.; Rabascio, C.; Talarico, G.; Orecchioni, S.; Manconi, A.; Bertolini, F. Adipose Progenitor Cell Secretion of GM-CSF and MMP9 Promotes a Stromal and Immunological Microenvironment That Supports Breast Cancer Progression. Cancer Res. 2017, 77, 5169-5182. [CrossRef] [PubMed]

25. Ghirelli, C.; Reyal, F.; Jeanmougin, M.; Zollinger, R.; Sirven, P.; Michea, P.; Caux, C.; Bendriss-Vermare, N.; Donnadieu, M.H.; Caly, M.; et al. Breast Cancer Cell-Derived GM-CSF Licenses Regulatory Th2 Induction by Plasmacytoid Predendritic Cells in Aggressive Disease Subtypes. Cancer Res. 2015, 75, 2775-2787. [CrossRef] [PubMed]

26. Aliper, A.M.; Frieden-Korovkina, V.P.; Buzdin, A.; Roumiantsev, S.A.; Zhavoronkov, A. A role for G-CSF and GM-CSF in nonmyeloid cancers. Cancer Med. 2014, 3, 737-746. [CrossRef] [PubMed]

27. Braun, B.; Lange, M.; Oeckler, R.; Mueller, M.M. Expression of G-CSF and GM-CSF in human meningiomas correlates with increased tumor proliferation and vascularization. J. Neuro-Oncol. 2004, 68, 131-140. [CrossRef]

28. Mueller, M.M.; Fusenig, N.E. Constitutive expression of G-CSF and GM-CSF in human skin carcinoma cells with functional consequence for tumor progression. Int. J. Cancer 1999, 83, 780-789. [CrossRef]

29. Kohanbash, G.; McKaveney, K.; Sakaki, M.; Ueda, R.; Mintz, A.H.; Amankulor, N.; Fujita, M.; Ohlfest, J.R.; Okada, H. GM-CSF promotes the immunosuppressive activity of glioma-infiltrating myeloid cells through interleukin-4 receptor-alpha. Cancer Res. 2013, 73, 6413-6423. [CrossRef]

30. Gutschalk, C.M.; Yanamandra, A.K.; Linde, N.; Meides, A.; Depner, S.; Mueller, M.M. GM-CSF enhances tumor invasion by elevated MMP-2, -9, and -26 expression. Cancer Med. 2013, 2, 117-129. [CrossRef]

31. Zhou, X.L.; Fan, W.; Yang, G.; Yu, M.X. The clinical significance of PR, ER, NF- kappa B, and TNF- alpha in breast cancer. Dis Markers 2014, 2014, 494581. [CrossRef] [PubMed]

32. Rubinow, K.B.; Wall, V.Z.; Nelson, J.; Mar, D.; Bomsztyk, K.; Askari, B.; Lai, M.A.; Smith, K.D.; Han, M.S.; Vivekanandan-Giri, A.; et al. Acyl-CoA synthetase 1 is induced by Gram-negative bacteria and lipopolysaccharide and is required for phospholipid turnover in stimulated macrophages. J. Biol. Chem. 2013, 288, 9957-9970. [CrossRef] [PubMed]

33. Koga, Y.; Hisada, T.; Ishizuka, T.; Utsugi, M.; Ono, A.; Yatomi, M.; Kamide, Y.; Aoki-Saito, H.; Tsurumaki, H.; Dobashi, K.; et al. CREB regulates TNF-alpha-induced GM-CSF secretion via p38 MAPK in human lung fibroblasts. Allergol. Int. Off. J. Jpn. Soc. Allergol. 2016, 65, 406-413. [CrossRef] [PubMed] 
34. Hashimoto, S.; Matsumoto, K.; Gon, Y.; Maruoka, S.; Kujime, K.; Hayashi, S.; Takeshita, I.; Horie, T. p38 MAP kinase regulates TNF alpha-, IL-1 alpha- and PAF-induced RANTES and GM-CSF production by human bronchial epithelial cells. Clin. Exp. Allergy J. Br. Soc. Allergy Clin. Immunol. 2000, 30, 48-55. [CrossRef] [PubMed]

35. Wray, G.M.; Foster, S.J.; Hinds, C.J.; Thiemermann, C. A cell wall component from pathogenic and non-pathogenic gram-positive bacteria (peptidoglycan) synergises with endotoxin to cause the release of tumour necrosis factor-alpha, nitric oxide production, shock, and multiple organ injury/dysfunction in the rat. Shock 2001, 15, 135-142. [CrossRef]

36. Al-Rashed, F.; Kochumon, S.; Usmani, S.; Sindhu, S.; Ahmad, R. Pam3CSK4 Induces MMP-9 Expression in Human Monocytic THP-1 Cells. Cell Physiol. Biochem. 2017, 41, 1993-2003. [CrossRef] [PubMed]

37. Sindhu, S.; Al-Roub, A.; Koshy, M.; Thomas, R.; Ahmad, R. Palmitate-Induced MMP-9 Expression in the Human Monocytic Cells is Mediated through the TLR4-MyD88 Dependent Mechanism. Cell Physiol. Biochem. 2016, 39, 889-900. [CrossRef]

38. Ahmad, R.; Shihab, P.K.; Jasem, S.; Behbehani, K. FSL-1 induces MMP-9 production through TLR-2 and NF- $\mathrm{KB}$ /AP-1 signaling pathways in monocytic THP-1 cells. Cell Physiol. Biochem. 2014, 34, 929-942. [CrossRef]

(C) 2019 by the authors. Licensee MDPI, Basel, Switzerland. This article is an open access article distributed under the terms and conditions of the Creative Commons Attribution (CC BY) license (http://creativecommons.org/licenses/by/4.0/). 